\title{
Degradation of tributyltin by marine microorganisms in sediment collected from Tokyo Bay
}

\author{
* NaOKO HAMADA-SATO, ${ }^{1}$ TAKAHIRO ASUKA, ${ }^{1}$ TAKESHI KOBAYASHI, ${ }^{1}$ CHIAKI IMADA, ${ }^{1}$ KaZUKO MIZUISHI, ${ }^{2}$ \\ MASAHIRO TAKEUCH, ${ }^{2}$ AND ETSUO WATANABE ${ }^{1}$ \\ ${ }^{1}$ Tokyo University of Fisheries, Minato-ku, Tokyo, 108-8477, Japan (hsnaoko@tokyo-u-fish.ac.jp), and ${ }^{2}$ The Tokyo \\ Metropolitan Research Laboratory of Public Health, Shinjuku-ku, Tokyo, 169-0073, Japan
}

KEYWORDS: tributyltin, marine microorganisms, degradation

\section{INTRODUCTION}

The environmental concem about the pollution of organotin compounds has increased considerably in recent years. Tributyltin (TBT) was most widely used as effective antifouling paints, wood preservatives and so on. The release of TBT from antifouling paints has been shown worldwide to be marine contamination and toxic to non-target biota such as gastropod. TBT has been considered as one of endocrine disrupter chemicals, responsible for the imposex syndrome in the female in several species of aquatic organisms. However, there have been a few researches conceming microbial breakdown of the discharged TBT and isolation of organotin-degrading microorganism. Recently Kawai et al. ${ }^{1)}$ reported that tributyl phosphate (TBP)-degrading terrestrial Pseudomonas strain also had ability to degrade TBT. No report, however, has been yet available conceming TBT-degrading marine organisms. Therefore, we investigated TBT-degrading activities of the microbes in the sediment collected from various areas and found a notable activity from Tokyo Bay. In addition, two types of bacteria that degraded TBT were isolated from the sample to apply them to marine bioremediation.

\section{MATERIALS AND METHODS}

\section{Materials}

Yeast Nitrogen Base (YNB) was purchased from Difco Laboratories, Detroit, MI, USA. Tributyltin chloride (TBuTCl) and tripentyltin chloride (TPenTCl) were obtained from Tokyo Kasei (Tokyo, Japan). TPenTCl was used as internal standard to correct for loss of extraction procedure and injection volume. Stock solutions of TBuTCl and TPenTCl were prepared by dilution with hexane. The solvent used for the extraction (hexane, methanol, ethylacetate and diethyl ether) of these organotins were analytical-reagent grade.

\section{Collection of samples and culture conditions}

Sediment samples were collected from various sea areas such as Tokyo Bay, Sagami Bay and Off-Boso during the KT-00-9 cruise on the research vessel Tansei-maru of the Ocean Research Institute, University of Tokyo using a multiple-corer sediment sampler. YNB medium prepared with artificial water containing $100 \mu \mathrm{g} / \mathrm{L}$ TBT was used for the isolation of TBT-degrading microbes. About $10 \mathrm{~g}$ of sediment sample was suspended in $100 \mathrm{ml}$ of the culture medium and an aliquot of $2 \mathrm{ml}$ was inoculated to $20 \mathrm{ml}$ of the same medium and incubated at $27^{\circ} \mathrm{C}$ for 21 days in the dark (first enrichment culture). After incubation, an aliquot of $200 \mu \mathrm{l}$ of the broth was transferred to fresh medium $(20 \mathrm{ml})$ and further incubated under the same conditions (second and third enrichment culture). Control experiments without sediment sample were also performed in order to detect possible non-biological elimination under the same conditions. In addition, autoclaved sediment samples were used as control during enrichment culture to inspect whether the degradation was participated by microorganism or not.

\section{Analytical procedure for TBT}

Sample preparation for culture media containing sediment sample was carried out according to the procedure shown in Fig. $1^{2)}$. 0.2 ng of $\mathrm{TPenCl}$ was added to culture medium as internal standard. Gas chromatography (GC) was performed on a Hewllett-Packard (Avondate, PA, USA) 5890 series II gas chromatograph equipped with a flame photometric detector (FPD) with a $611.6 \mathrm{~nm}$ filter. The GC column used was a fused-silica capillary column $(15 \mathrm{~m} \times 0.25$ $\mathrm{mm}$ id) coated with DB-1 (0.1 $\mu \mathrm{m}$ film thickness) (J\&W) Scientific, Rancho Cordova, CA, USA).

16S rDNA analysis

Total bacterial DNA was obtained by ordinary method. ${ }^{3)}$ Subsequently, a partial region of the $16 \mathrm{~S}$ rDNA was amplified PCR using Taq DNA polymerase (Takara 
Shuzo, Kyoto) and primer set, corresponding to positions 8-27 (forward primer) and 1492-1510 (reverse primer) was used. The thermal profile involved 25 cycles: $94{ }^{\circ} \mathrm{C}$ for $60 \mathrm{~s}, 60^{\circ} \mathrm{C}$ for $60 \mathrm{~s}$, and $72^{\circ} \mathrm{C}$ for $90 \mathrm{~s}$, with a final polymerization at $72^{\circ} \mathrm{C}$ for $5 \mathrm{~min}$. The reaction mixture was analyzed with an Applied Biosystems 373A DNA sequencer (Perkin-Elmer, Foster City, CA). The obtained nucleotide sequences were subjected to the similarity search program BLAST.

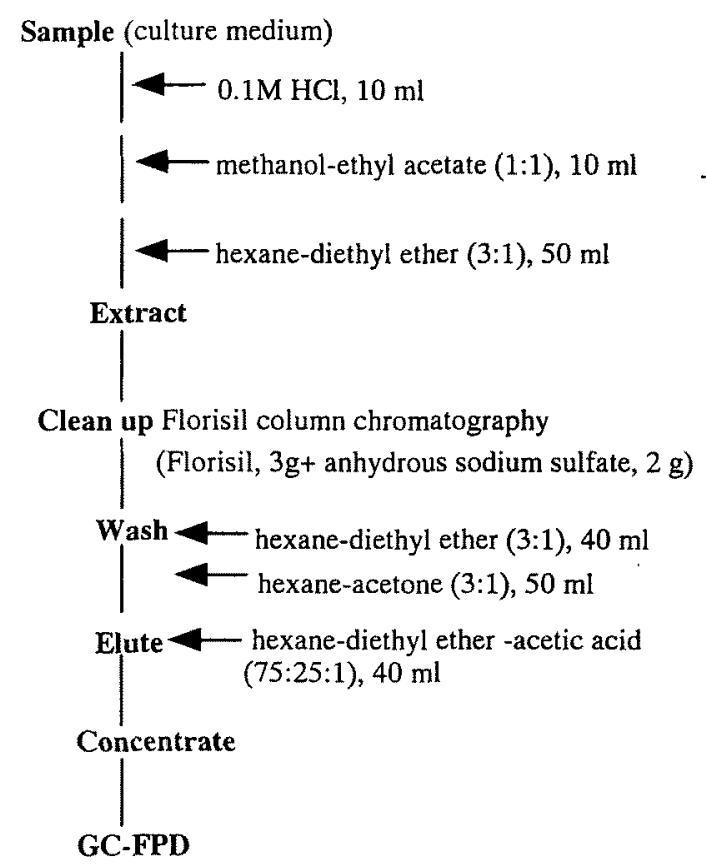

Fig. 1 Sample preparation procedure for TBT in culture medium

\section{RESULTS AND DISCUSSION}

\section{Degradation of TBT in the sediment samples} collected from each station

Degradation of TBT in the sediment samples collected from each sample station is shown in Table 1 . The ratio of degradation of TBT in third enrichment culture was summarized in Table 1. TBT-degrading activity was detected in 6 stations. The strongest activity (72.7\%) was detected in St. 4 sediment sample, suggesting that TBT-degrading microorganisms exist widely in the marine environment.

Table 1 Degradation of TBT in the sediments samples collected from each station

\begin{tabular}{ccccccc}
\hline $\begin{array}{c}\text { St. } \\
\text { No. }\end{array}$ & Sea area & $\begin{array}{c}\text { Latitude } \\
(\mathrm{N})\end{array}$ & $\begin{array}{c}\text { Longitude } \\
(\mathrm{E})\end{array}$ & $\begin{array}{c}\text { Depth } \\
(\mathrm{m})\end{array}$ & $\begin{array}{c}\text { Percentage } \\
\text { of TBT } \\
\text { degraded }\end{array}$ \\
\hline 1 & $\begin{array}{c}\text { Tokyo } \\
\text { Bay }\end{array}$ & $35^{\circ} 34.0^{\prime}$ & $139^{\circ} 59.0^{\prime}$ & 31 & 0 \\
\hline
\end{tabular}

\begin{tabular}{lcllllll}
\hline 2 & $\begin{array}{c}\text { Tokyo } \\
\text { Bay }\end{array}$ & $35^{\circ}$ & $30.1^{\prime}$ & $139^{\circ}$ & $52.4^{\prime}$ & 15 & 13.3 \\
3 & $\begin{array}{c}\text { Tokyo } \\
\text { Bay }\end{array}$ & $35^{\circ}$ & $27.1^{\prime}$ & $139^{\circ}$ & $50.1^{\prime}$ & 15 & 0 \\
4 & $\begin{array}{c}\text { Tokyo } \\
\text { Bay }\end{array}$ & $35^{\circ}$ & $21.0^{\prime}$ & $139^{\circ}$ & $47.0^{\prime}$ & 12 & 72.7 \\
5 & $\begin{array}{c}\text { Tokyo } \\
\text { Bay }\end{array}$ & $35^{\circ}$ & $11.3^{\prime}$ & $139^{\circ}$ & $44.9^{\prime}$ & 134 & 0 \\
6 & $\begin{array}{c}\text { Sagami } \\
\text { Bay }\end{array}$ & $35^{\circ}$ & $04.5^{\prime}$ & $139^{\circ}$ & $39.1^{\prime}$ & 122 & 33.3 \\
7 & $\begin{array}{c}\text { Sagami } \\
\text { Bay }\end{array}$ & $35^{\circ} 00.1^{\prime}$ & $139^{\circ}$ & $20.0^{\prime}$ & 1504 & 40.0 \\
8 & $\begin{array}{c}\text { Off-Bos } \\
\mathbf{0}\end{array}$ & $34^{\circ} 29.8^{\prime}$ & $139^{\circ} 05.8^{\prime}$ & 6517 & 53.3 \\
9 & $\begin{array}{c}\text { Off-Bos } \\
\mathbf{0}\end{array}$ & $34^{\circ} 33.1^{\prime}$ & $141^{\circ} 54.0^{\prime}$ & 6347 & 53.3 \\
\hline
\end{tabular}

Isolation and characterization of TBT-degrading microorganisms

From third enrichment culture collected from St. 4 sediment sample, two microorganisms were isolated on YNB medium. These strains were named as HA-T and HB-N and inoculated into the same medium containing $100 \mu \mathrm{g} / \mathrm{L}$ (pure culture conditions) and degradation of TBT was determined. These strains could degrade TBT independently. HA-T strain could degrade $60 \mu \mathrm{g} / \mathrm{L}$. Whereas, HB-N strain degrade about $97 \mu \mathrm{g} / \mathrm{L}$ of TBT after 21days incubation. From 16S rDNA gene sequence analysis, HA-T strain was found to have a high homology with Halomonas aquamarina (97\%). On the other hand, HB-N strain had close similarity with Halomonas alimentaria (98\%). Further physiological and biochemical characterization as well as the application on the marine bioremediation is under way.

\section{REFERENCES}

1. Kawai S, Kurokawa $Y$, Harino $H$, Fukushima $M$. Degradation of tributyltin by a bacterial strain isolated from polluted river water. Environmental Pollution, 1998; 102 : 259-263.

2. Mizuishi, K, Takeuchi, M, Hobo, T. Effect of hydrogen bromide doping on capillary gas chromatographic analysis of tributyltin and triphenyltin halides . Analyst, 1998;123:329-335.

3. Sambrook J, Fritsch E, Maniatis T. Molecular cloning. A Laboratory Manual, 2nd edn. Cold Spring Harbor Laboratory Press, New York. 1989. 